\title{
The race/color variable in studies of
}

\section{characterization of the users of Psychosocial \\ Care Centers'}

\section{o quesito raça/cor nos estudos de caracterização de usuários de Centro de Atenção Psicossocial}

\author{
Naiara Gajo Silva \\ Universidade de São Paulo. Escola de Enfermagem. São Paulo, \\ SP, Brazil. \\ E-mail: naiaragajosळgmail.com

\section{Sônia Barros} \\ Universidade de São Paulo. Escola de Enfermagem. São Paulo, \\ SP, Brazil. \\ E-mail: sobarrosळusp.br

\section{Fernanda Christiane de Azevedo} \\ Universidade de São Paulo. Escola de Enfermagem. São Paulo, \\ SP, Brazil. \\ E-mail: fernanda.azevedoळusp.br

\section{Luís Eduardo Batista} \\ Universidade de São Paulo. Escola de Enfermagem. São Paulo, \\ SP, Brazil. \\ E-mail: lebatistaळsaude.sp.gov.br

\section{Valéria Camargo Policarpo} \\ Universidade de São Paulo. Escola de Enfermagem. São Paulo, \\ SP, Brazil. \\ E-mail: valeria.policarpo®usp.br
}

\section{Correspondence}

Naiara Gajo Silva

Avenida Dr. Enéas de Carvalho Aguiar, 419, 20 andar, Cerqueira César. São Paulo, SP, Brazil. CEP 05403-000.

\section{Abstract}

Based on the review of the scientific literature, this study aims to present the profile of the users who attend Psychosocial Care Centers (PCCs) to verify if the race/color factor is considered in it. We carried out the bibliographic research between May and August 2015 on Scholar Google and on the Virtual Health Library databases: Medline, BDENF, Paho, Index Psicologia and Lilacs. Our search strategies were: (1) "mental health services"/ "serviços de saúde mental" AND "epidemiological profile" "perfil epidemiológico" and (2) "mental health services"/"serviços de saúde mental" AND "health profile"/"perfil de saúde". Two reviewers assessed the titles and abstracts of $45^{2}$ articles retrieved. Thus, we deleted the repeated articles and those that did not meet the profile of PCCs users, remaining 17 of them. From these, only three articles had data on race/color, but none of them developed a discussion on this information. We found out that two PCCs proportionally have more black patients compared with any other population and that the use of race/color to characterize users of PCCs services is still not so common, despite being considered an important social marker - this is how the Brazilian society deals with racial inequalities: as they were not real, which contributes to their strengthening. These inequalities have shown to be persistent, making it necessary for academics and public health managers to go beyond the recommendations of the conferences and define strategies to face such issues, thus producing and

I Study presented at I Seminário Internacional sobre avaliação da qualidade da atenção em saúde de populações vulneráveis: pessoas com transtorno mental, usuário de álcool e outras drogas e população negra [1st International Conference on Quality of Health Care provided to vulnerable populations: people with mental disorders, alcoholics, drug users and the black population]. São Paulo, Brazil, November 12 
reproducing helpful knowledge in its developing and implementation of these measures.

Keywords: Group of Descendants of the African Continent; Mental Health Services; Epidemiological Profile.

\section{Resumo}

Este trabalho teve como objetivo apresentar, por meio de revisão narrativa da literatura científica, o perfil dos usuários atendidos em Centros de Atenção Psicossocial (CAPS), para verificar a inclusão do quesito raça/cor nessa produção. O levantamento bibliográfico foi realizado de maio a agosto de 2015 no Google Acadêmico e em bases que compõem a Biblioteca Virtual de Saúde: Medline, BDENF, Paho, Index Psicologia e Lilacs. As estratégias de busca foram: (1) "mental health services"/"serviços de saúde mental" AND "epidemiological profile"/"perfil epidemiológico" e (2) "mental health services"/"serviços de saúde mental" AND "health profile"/"perfil de saúde". Dois revisores avaliaram títulos e resumos dos 452 artigos recuperados. A partir disso, foram excluídos os artigos repetidos e os que não tratam do perfil de usuários de CAPS, restando então 17 artigos. Desses, apenas três apresentaram dados de raça/cor, mas nenhum discutiu esses dados. Verificouse que dois CAPS têm proporcionalmente mais negros em tratamento do que a população em geral, e evidenciou-se que o uso da variável raça/ cor para caracterizar usuários dos serviços de CAPS ainda é reduzido, mesmo que seja importante marcador de cunho social - isso vai ao encontro da maneira como as desigualdades raciais no Brasil são tratadas pela sociedade: como inexistentes, o que reforça as iniquidades. Essas desigualdades têm se revelado persistentes e requerem que a política de saúde mental e a academia iniciem discussão que vá além de recomendações de conferências, para que se definam estratégias para esse enfrentamento e se produzam e reproduzam conhecimentos que possam ajudar na elaboração e implementação dessas estratégias.

Palavras-chave: Grupo com Ancestrais do Continente Africano; Serviços de Saúde Mental; Perfil Epidemiológico.

\section{Introduction}

In 2010, the Brazilian population was $47.7 \%$ $(91,051,647)$ composed by white people; $43.1 \%$ $(82,277,333)$ were brown; $7.6 \%(14,517,961)$ were black; $1.1 \%(2,084,288)$ were yellow; $0.4 \%(817,963)$ were indigenous people; and $0.003 \%(6,608)$ were inhabitants whose color had not been declared (IBGE, 2012). Identifying that $50.7 \%$ of the population consists of black and brown people, both groups being considered part of the black community, it becomes clear that Brazil is a country whose inhabitants are mostly black. Despite that, this population has a lower education level and lower income compared with the population of white people. In a brief overview of this disparity, data from IBGE show that $27.4 \%$ of black people above 15 years were illiterate, only $13.1 \%$ of them with age between 15 and 24 years attended higher education institutions, and $24 \%$ were employed in informal jobs without official registration (IBGE, 2012); in addition, the average monthly income of black people was only R\$ 847,70 (IBGE, 2009). Among the white population of the same age group, $5.9 \%$ were illiterate and $31.1 \%$ of them attended higher education institutions; the percentage of white employees in informal jobs without official registration was of $16.3 \%$ (IBGE, 2012) and their average income was of $R \$ 1,663.90$ (IBGE, 2009).

Primary disadvantages created by slavery, the nature of the abolition, subsequent absence of public policies on education and workforce, lack of material, social isolation and restrictions on political participation of blacks in Brazil have contributed and still contribute to the formation and maintenance of this scenario (Araújo et al., 2009). This process of disqualified social inclusion and restriction of access to goods and social services, experienced by blacks in Brazil, is known as racism.

The association between racism, health and vulnerable populations has gained space in scientific literature. The impact of racism on health, illness and death has been discussed by several authors, of which we highlight Araújo et al. (2009); Araújo et al. (2012); Barbosa (1998); Batista; Escuder; Pereira (2004) and Lopes (2005). 
Considering individual and population groups differences, the promotion of health care must be discussed in the context of the Brazilian Unified Health System (SUS) by adapting the offer to health needs and extending users access to policies, especially the ones for populations in situations of inequality due to genetic factors, social exclusion conditions, and ethnic and racial inequalities (Barros; Campos; Fernandes, 2014). Vulnerability due to social, cultural, political and economic matters and a consequence of inequality can affect in an individual or collective way, among individuals, different groups, different cultures or ethnicities regarding a wider group, or even among countries. In the mental health field, Barros et al. (2014, p. 1238), among others, discussed the association between racism, scientific racism, vulnerabilities and the implementation of subtle mechanisms of social control in the history of Brazilian psychiatry.

Among the themes privileged by Brazilian mental health specialists and psychiatrists when dealing with actions, habits, behaviors, beliefs and "deviant" values there are: civilization, race/color, sexuality, work, alcoholism, crime, religious fanaticism, and political contestation (Engel, 1999). Placing "individuals and uncomfortable social sectors under suspicion”, psychiatric knowledge was used to come into an effective strategy to fix "personal and social behaviors that differ from moral standards" (Cunha, 1986, p. 47 apud Engel, 1999). According to Engel (1999), the connection between race/color and mental disorders gives another important clue to assess the political and social dimensions of mental health knowledge and practice in Brazilian society in recent decades of the 19th century. Always willing to preserve the extension and imprecision of mental disorders defining boundaries, psychiatrists assumed that madness did not choose color, which had not stopped them from establishing associations between mental disorders and races considered inferior. For example, they came up with the idea that black people and especially mixed race people were predisposed to madness for being degenerate people. However, even when not classified as degenerate, black and brown individuals were seen as intellectually inferior and therefore less capable of confronting and/or adapting to the contingencies of the social environment, this way being "more predisposed" to degeneration. [...] The psychosocial effects of racism is a recent way of interpreting the mental health issue in Brazil. In addition, we have to question if the eugenic thought is still part of the formation of health professionals, contributing to the social representation of professionals on madness.

In the context of the Brazilian psychiatric reform, community services are the primary strategy in the care of people suffering from mental health disorders. In the framework of deinstitutionalization, the psychiatric hospital is no longer a place for treatment, and the access to services such as the Psychosocial Care Centers (PCCs) presumes the understanding of the subject's psychosocial history. However, the psychosocial effects of racism have been little studied in the context of the reform or the services. However, approaching this theme is important when it comes to health care and also from the perspective of aggravations in the process of health and mental disorders, but also from psychosocial rehabilitation and inclusion, and aims concerning mental health care.

Kwate and Goodman (2015) call attention to methodological difficulty in proving the association between exposure to racism and the development of mental disorders with longitudinal section studies, which makes these studies expensive. However, the experience of racism has proven association with feelings of loneliness among young people (Priest et al., 2014), days of poor mental health (Kwate; Goodman, 2015) and symptoms of anxiety and depression (Pieterse et al., 2012).

In a study conducted with death records of inhabitants of the State of São Paulo during the years 1999, 2000 and 2001, it was found that mental disorders were the fourth most important cause of death among black people and the third among brown, not being listed among the characteristic causes of death in order of importance between white people (Batista; Escuder; Pereira, 2004).

Barros et al. (2014) showed that among people admitted to psychiatric hospitals for more than 
one year, black ones with mental disorders were in higher percentage compared to the white ones, results calculated proportionally with the population of São Paulo. However, these studies were not enough to make managers include racism in their management plans and strategies.

Considering the chance that in Brazilian society there are several processes on prejudice, abandoning and social exclusion of vulnerable populations, Barros et al. (2014) revisited the Psychosocial Census database of the State of São Paulo (Barros; Bichaff, 2008) to describe the profile of residents of psychiatric hospitals and characterize their clinical profile according to race/color, concluding that:

(1) census data of residents of psychiatric hospitals of the State of São Paulo, Brazil, show that the black population is sadly placed in the first position of the ranking of social exclusion; the age range of black and brown residents admitted was between 35 and 49 years. It raises the possibility that black and brown people attended these hospitals at younger ages and remained hospitalized;

(2) there is a higher proportion of black people who were admitted because they had no income, family or place to live, neither had a strong social network. This social precarity is associated with mental disorders or clinical diseases;

(3) the black population historically suffers uninterrupted processes of abandoning and social exclusion. The place par excellence of abandoning and exclusion is the asylum, besides other institutions.

Rosa and Vilhena (2012) call attention to the "diversity" theme in discussions in the mental health field, reinforcing the need for the strengthening of policies to promote equality, as well as combating inequality, stigmas and stereotypes. In this sense, the authors highlight the recommendations in the final reports of the III National Conference on Mental Health - to emphasize the development of research that investigate the impact of racism on mental health of black and indigenous population - and of the IV National Conference on Mental Health-Sector
- on the fighting of inequalities, stigmas and stereotypes, as well as on the development of specific cutouts of race and ethnicity in the development, implementation and execution of public policies in the mental health field.

Differently from mental hospitals, PCCs purpose is to promote social inclusion of people with mental disorders (Brazil, 2004). Currently, there are no studies that address the black population's access to services offered by PCCs, showing the use of the race/color variable, which carries the weight of Brazilian history and culture is still scarce in the health field (Araújo et al., 2009). Thus, it is important to check if the inclusion of the black population in community services on mental health has been the subject of studies by the scientific community.

With these considerations, the aim of this article is to descriptively present, by reviewing the scientific literature, the profile of residents of PCCs to check the inclusion of the race/color variable in this production.

\section{Methodology}

A literature review of narrative type was conducted with a quantitative approach. This type of review has been used to study characteristics of certain populations such as the morbidity profile of commercial pilots (Melo; Silvany Neto, 2012), physical aspects and measuring of military performance (MacDonald; Pope; Orr, 2016), and health networks (Trapé; Campos; Gama, 2015). The choice for adopting this methodology was due to the fact that in this type of study the bibliographical production is analyzed by providing the art status of a given object as well as highlighting themes that have received greater or lesser emphasis in the selected literature (Noronha; Fernandez, 20oo).

Bibliographic research was conducted between May and August 2015 in Scholar Google and data from the Virtual Health Library databases: Medline, BDENF, Paho, Index Psicologia and Lilacs. We opted for these databases considering they have a greater number of publications in national journals, which meets the profile/characteristics of users of PCCs, a specific service of the Brazilian context. The strategies used in the search were composed by the follow- 
ing descriptors on health sciences (DeHs): (1) "mental health services"/ "serviços de saúde mental" AND "epidemiological profile"/"perfil epidemiológico" and (2) "mental health services"/ "serviços de saúde mental" AND "health profile"/"perfil de saúde".

\section{Extraction and analysis of data}

Two reviewers independently evaluated the titles, abstracts and the indexing information of 452 scientific articles retrieved. The full version of the article was only obtained if the following inclusion criteria were present: subject of research users of PCCs; format of publication of scientific article; non-experimental methodological characteristic and epidemiological data of the population attended in PCCs; written languages in Portuguese, English or Spanish. There were no restrictions on the publication date.
From reading the abstracts and excluding the repeated articles, 17 of them were selected, as shown in Figure 1.

After fully reading the material, data on the epidemiological profile of users were put on the Excel program for its comparison and analysis. The option to use the "black category", which includes blacks and browns, came up as an alternative to the no standardization of articles regarding the use of the terminology "skin color" as black and brown. Data discussion was carried out considering the absence and the presence of information.

\section{Results}

The corpus of this study comprised 17 articles published between 2005 and 2014, presenting the profile/characteristics of 7,609 users of PCCs. The locals of study of such publications were four

Figure I - Chart with article selection, São Paulo, 2015

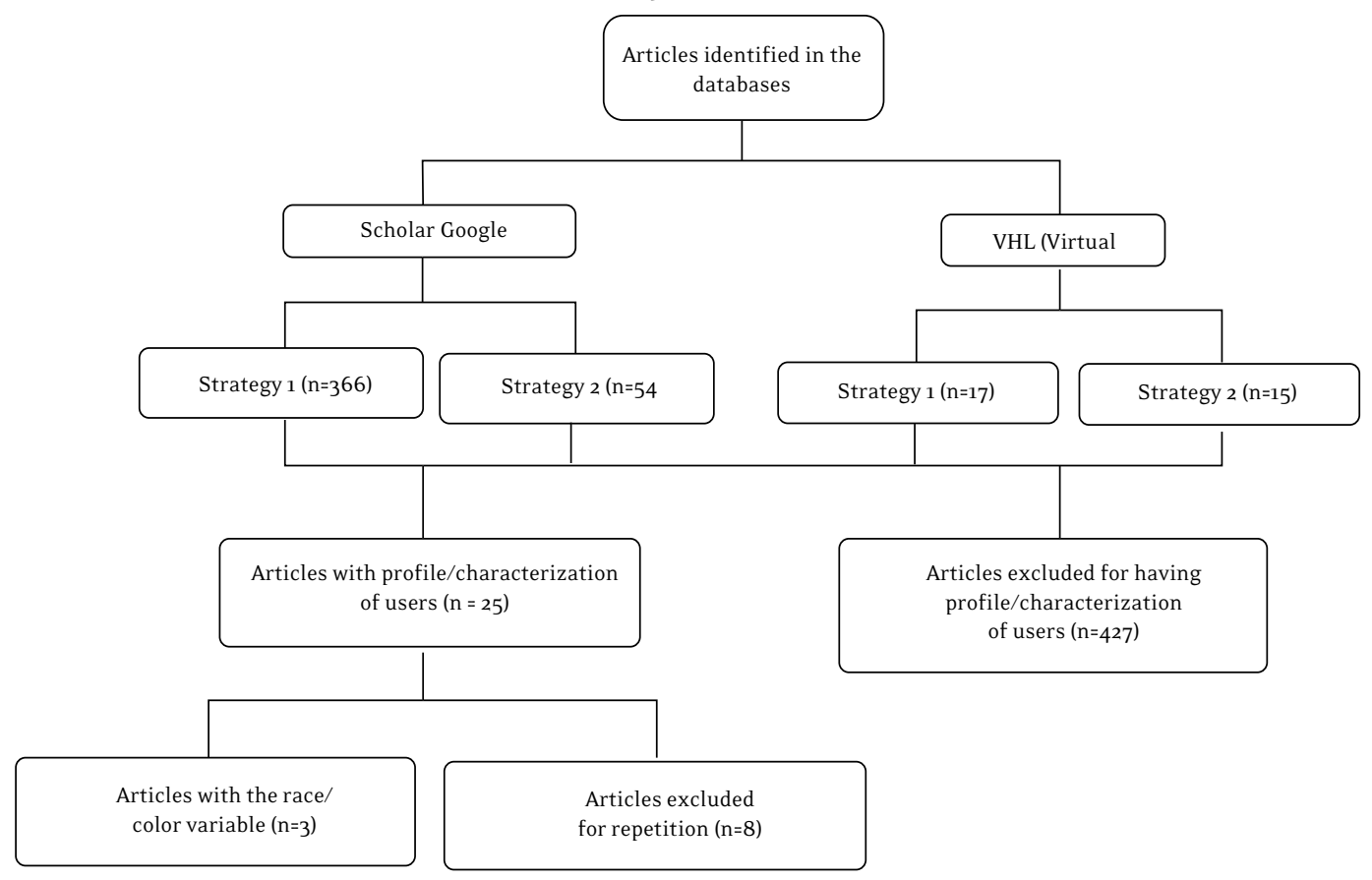


alcohol and drugs PCCs (adPCCs), two children and adolescents' PCCs (caPCCs), and 10 adult PCCs (I, II or III), one of these being the local of study of two researches. The studies present data from PCCs users from cities of four regions of the country, namely: (1) Southeast - Barbacena, Contagem, Uberlândia and Uberaba, in Minas Gerais; Lorena, Sorocaba and Campinas, in São Paulo; (2) Midwest - Cuiabá, in Mato Grosso; (3) Northeast - Maceió, in Alagoas; Fortaleza, Iguatu and Sobral, in Ceará; Recife, in Pernambuco; Jequié and Ilhéus, in Bahia; João Pessoa, in Paraíba; and (4) South - Orleans, in Santa Catarina; Cambé and Londrina, in Paraná; Alegrete, Bagé, Caxias do Sul, Porto Alegre, Viamão and Osório, in Rio Grande do Sul.

We collected the data by analyzing medical records, undertaking interviews and also analyzing the Outpatient Information System (OIS); the sample ranged between 35 and 2,470 users or medical records. Among 17 articles, 11 of them showed prevalence of male users of PCC; regarding the education level of the users, 7 articles described that users reported having complete middle school; on the use of psychoactive substances, alcohol and tobacco were the most commonly used drugs, according to some studies (Table 1).

The prevalence of the results obtained in the studies was of schizophrenia/schizotypal and delusional disorders (19\%), followed by mood disorders (15\%) and behavioral and emotional disorders (10\%). Among the users of PCC, $56 \%$ were male and $57 \%$ of them were single, their average age being of 34.2 years. Regarding the education of users, $9 \%$ of them were illiterate or had no education, $55 \%$ had some elementary school or have finished it, $19 \%$ had some high school or have finished it, and only $4 \%$ had higher education institutions or have finished it. As for their job situation, most of them (36\%) were unemployed, $7 \%$ received some kind of benefit, and $7 \%$ were retired, considering the variables "receive some kind of benefit" and "retired" were calculated together in two articles (article 5 and 11 ), representing $2 \%$ of the job situation of these users; $24 \%$ of these users were employed, selfemployed, or worked in informal jobs.

Most clinical and medical care variables were common in the articles, regardless of the specialty of the PCC under study; however, we observed some specificities in users of adPCC and caPCC - for example, in studies that had as target population the users of caPPC, these specificities were school report and job situation of the parents (Nascimento et al., 2014); frequency and time of use of psychoactive substance and damages caused by it were added in adPCC, in addition to problems with justice, considering the specificity of each service (Almeira et al., 2014; Araújo et al., 2012; Oliveira et al., 2013; Rodrigues et al., 2013).

Only three of 17 articles used the variable race/ color in the description of the service users, in which the proportion of black people was of $77.5 \%$ (Almeida et al., 2014), 27.4\% (Pereira et al., 2012) and $29.1 \%$ (Rodrigues et al., 2012), approaching the states of Paraíba, São Paulo and Rio Grande do Sul, respectively, while in the same period the proportion of black people in these states was of $58.4 \%, 34.6 \%$ and $16.2 \%$ (IBGE, 2012), according with Chart 1. Despite presenting data on this variable, none of the three articles discussed the data they found, i.e., race/color was not considered in the discussion.

\section{Chart I - Race/color characterization of PCCs users according to the analyzed articles, São Paulo, 2015}

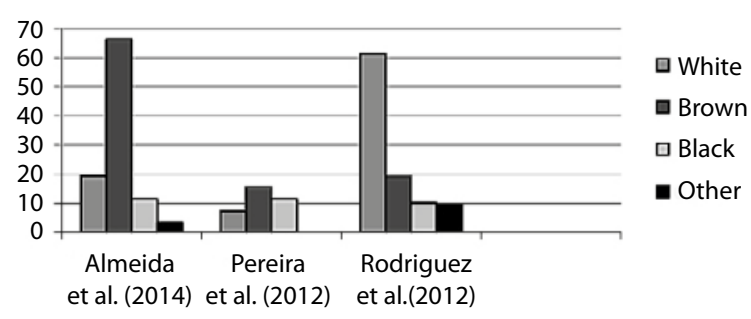


Table I - Articles included according to authors, year of publication, journal, affiliation, local of study, size of the sample, empirical material and synthesis of the users' profile, São Paulo, 2015

\begin{tabular}{|c|c|c|c|c|c|c|c|}
\hline & Article & Journal & $\begin{array}{l}\text { Institutional } \\
\text { affiliation of the } \\
\text { authors }\end{array}$ & Local of study & $\begin{array}{l}\text { Size of the } \\
\text { sample }\end{array}$ & $\begin{array}{l}\text { Empirical } \\
\text { material }\end{array}$ & Synthesis of the users' profile \\
\hline 1 & $\begin{array}{l}\text { Rodrigues et al. (2013) } \\
\text { Profile of users who } \\
\text { attend Psychosocial Care } \\
\text { Centers - alcohol and } \\
\text { drugs }\end{array}$ & $\begin{array}{l}\text { Revista de } \\
\text { Enfermagem } \\
\text { UFPE Online } \\
\text { [Journal of } \\
\text { nursing UFPE } \\
\text { Online] }\end{array}$ & $\begin{array}{l}\text { State University } \\
\text { of Southwest of } \\
\text { Bahia (UESB) }\end{array}$ & $\begin{array}{l}\text { adPCC-Jequié } \\
\text { (Bahia) }\end{array}$ & 221 & $\begin{array}{l}\text { Medical } \\
\text { record }\end{array}$ & $\begin{array}{l}\text { Men; catholics; average age of } 40,86 \\
\text { years; elementary school; damaged } \\
\text { social relationships; undergoing the } \\
\text { first treatment for the use alcohol and } \\
\text { other drugs. Prevalence of tobacco and } \\
\text { alcohol abuse. }\end{array}$ \\
\hline 2 & $\begin{array}{l}\text { Almeida et al. (2014) } \\
\text { Users profile of } \\
\text { psychoactive substances } \\
\text { of João Pessoa }\end{array}$ & $\begin{array}{l}\text { Saúde em } \\
\text { Debate [Health } \\
\text { in Discussion] }\end{array}$ & $\begin{array}{l}\text { Federal } \\
\text { University of } \\
\text { Paraiba (UFPB) }\end{array}$ & $\begin{array}{l}\text { III Adult PCC } \\
\text { - João Pessoa } \\
\text { (PB) }\end{array}$ & 706 & $\begin{array}{l}\text { Medical } \\
\text { record }\end{array}$ & $\begin{array}{l}\text { Men; from } 2 \text { to } 40 \text { years; brown; single; } \\
\text { low education level; unemployed. } \\
\text { Prevalence of tobacco and alcohol } \\
\text { abuse. Most people never underwent } \\
\text { hospitalization, and began treatment } \\
\text { spontaneously. }\end{array}$ \\
\hline 3 & $\begin{array}{l}\text { Costa et al. (2015) } \\
\text { Epidemiological profile of } \\
\text { intensive care users of a } \\
\text { Psychosocial Care Center }\end{array}$ & $\begin{array}{l}\text { Revista de } \\
\text { Enfermagem } \\
\text { UFPE Online } \\
\text { [Journal of } \\
\text { nursing UFPE } \\
\text { Online] }\end{array}$ & $\begin{array}{l}\text { State University } \\
\text { of Ceará (Uece) } \\
\text { and Federal } \\
\text { University of } \\
\text { Ceará (UFC) }\end{array}$ & $\begin{array}{l}\text { Adult PCC - } \\
\text { Fortaleza (CE) }\end{array}$ & 35 & $\begin{array}{l}\text { Medical } \\
\text { records }\end{array}$ & $\begin{array}{l}\text { Women; from } 33 \text { to } 44 \text { years; single; } \\
\text { Catholics; some elementary school; } \\
\text { income of one minimum wage. Starting } \\
\text { treatment due to psychiatric guiding } \\
\text { of the hospital of the region. The most } \\
\text { commonly seen symptom ( } 13 \% \text { ) was } \\
\text { hallucination and the most commonly } \\
\text { prescribed medications were Haloperidol } \\
\text { and Chlorpromazine. }\end{array}$ \\
\hline 4 & $\begin{array}{l}\text { Pelisoli and Moreira } \\
\text { (2005) } \\
\text { Epidemiological } \\
\text { characterization of } \\
\text { users of Casa Aberta } \\
\text { Psychosocial Care Center. }\end{array}$ & $\begin{array}{l}\text { Revista } \\
\text { Psiquiátrica do } \\
\text { Rio Grande do } \\
\text { Sul [Psychiatric } \\
\text { Journal of Rio } \\
\text { Grande do Sul] }\end{array}$ & $\begin{array}{l}\text { CNEC Faculty } \\
\text { of Osório } \\
\text { [Faculdade } \\
\text { Cenecista de } \\
\text { Osório (Facos)] }\end{array}$ & $\begin{array}{l}\text { Adult PCC - } \\
\text { Osório (RS) }\end{array}$ & 2,470 & $\begin{array}{l}\text { Medical } \\
\text { records }\end{array}$ & $\begin{array}{l}\text { Women; average age of } 30,35 \text { years; } \\
\text { students ( } 27.4 \%) \text {. The most common } \\
\text { diagnosis (22.4\%) was anxiety, and the } \\
\text { most commonly used medication ( } 15.8 \%) \\
\text { was Fluoxetine. }\end{array}$ \\
\hline 5 & $\begin{array}{l}\text { Oliveira et al. (2013) } \\
\text { Characterization of } \\
\text { people treated in } \\
\text { Psychosocial Care Center } \\
\text { - alcohol and drugs }\end{array}$ & $\begin{array}{l}\text { Revista Rene } \\
\text { [Rene Journal] }\end{array}$ & $\begin{array}{l}\text { Federal } \\
\text { University of } \\
\text { Ceará (UFC) and } \\
\text { adPCC Sobral }\end{array}$ & $\begin{array}{l}\text { adPCC - } \\
\text { Sobral (EC) }\end{array}$ & 300 & $\begin{array}{l}\text { Medical } \\
\text { records }\end{array}$ & $\begin{array}{l}\text { About } 75 \% \text { were men; } 44.3 \% \text { of them with II } \\
\text { to } 29 \text { years; } 49.0 \% \text { single; } 45.7 \% \text { with some } \\
\text { elementary school; } 53 \% \text { with some kind of } \\
\text { paid occupation. The most consumed drug } \\
\text { among men was crack (31.3\%), and among } \\
\text { women it was tobacco ( } 12 \% \text { ); the losses } \\
\text { associated with addiction were mostly } \\
\text { concerning family (31.3\%). }\end{array}$ \\
\hline 6 & $\begin{array}{l}\text { Bellettini and Gomes } \\
\text { (2013) } \\
\text { Profile of users of PCCs } \\
\text { and of the Mental Health } \\
\text { Program in the city of } \\
\text { Orleans-SC }\end{array}$ & $\begin{array}{l}\text { Cadernos } \\
\text { Brasileiros de } \\
\text { Saúde Mental } \\
\text { [Brazilian Notes } \\
\text { on Mental } \\
\text { Health] }\end{array}$ & $\begin{array}{l}\text { Centro } \\
\text { Universitário } \\
\text { Barriga Verde } \\
\text { (Unibave) } \\
\text { [University } \\
\text { Center of Santa } \\
\text { Catarina] }\end{array}$ & $\begin{array}{l}\text { PCC I-Orlens } \\
(\mathrm{SC})\end{array}$ & 208 & $\begin{array}{l}\text { Medical } \\
\text { records }\end{array}$ & $\begin{array}{l}\text { About } 65 \% \text { of women; from } 41 \text { to } 50 \text { years } \\
\text { ( } 37 \%) \text {. The most frequent diagnostic } \\
\text { hypothesis ( } 38 \% \text { ) is of disorders clas- } \\
\text { sified by ICD-10 between } \mathrm{F}_{30} \text { and } \mathrm{F} 39 \\
\text { (mood disorders). } 37 \% \text { of them under- } \\
\text { went psychiatric hospitalization, } 99 \% \\
\text { received psychiatric care, } 87 \% \text { received } \\
\text { psychological care, and } 98 \% \text { used psy- } \\
\text { choactive drugs. }\end{array}$ \\
\hline
\end{tabular}




\begin{tabular}{|c|c|c|c|c|c|c|c|}
\hline & Article & Journal & $\begin{array}{l}\text { Institutional } \\
\text { affiliation of the } \\
\text { authors }\end{array}$ & Local of study & $\begin{array}{l}\text { Size of the } \\
\text { sample }\end{array}$ & $\begin{array}{l}\text { Empirical } \\
\text { material }\end{array}$ & Synthesis of the users' profile \\
\hline 7 & $\begin{array}{l}\text { Carvalho, Silva and } \\
\text { Rodrigues (2010) } \\
\text { Epidemiological profile } \\
\text { of users of mental health } \\
\text { networks of the city of } \\
\text { Iguatu, CE }\end{array}$ & $\begin{array}{l}\text { SMAD - Revista } \\
\text { Eletrônica Saúde } \\
\text { Mental Álcoole } \\
\text { Drogas [MHAD } \\
\text { - Electronic } \\
\text { Journal of } \\
\text { Mental Health, } \\
\text { Alcohol and } \\
\text { Drugs) }\end{array}$ & $\begin{array}{l}\text { Regional } \\
\text { University of } \\
\text { Cariri }\end{array}$ & $\begin{array}{l}\text { adPCC, acPCC } \\
\text { and Adult PCC } \\
\text { - Iguatu (CE) }\end{array}$ & 143 & $\begin{array}{l}\text { Medical } \\
\text { records }\end{array}$ & $\begin{array}{l}79.3 \% \text { were women; } 51.7 \% \text { of them were } \\
\text { married; } 39.7 \% \text { had from } 4 \text { to } 7 \text { years of } \\
\text { study; } 20.7 \% \text { had a household income } \\
\text { from I to } 2 \text { minimum wages. For } 69 \% \text { of } \\
\text { patients, the main reason of search for } \\
\text { this service was their families; the most } \\
\text { common therapeutic activity was indi- } \\
\text { vidual medical appointments; the main } \\
\text { therapeutic conduct is the continuous use } \\
\text { of psychotropic drugs (Ioo\%); monthly } \\
\text { appointments were the most frequent } \\
\text { (37.9\%), without prior psychiatric hos- } \\
\text { pitalization ( } 63.8 \% \text { ). }\end{array}$ \\
\hline 8 & $\begin{array}{l}\text { Mangualde et al. (2013) } \\
\text { Epidemiological profile } \\
\text { of patients who attended } \\
\text { a Psychosocial Health } \\
\text { Center }\end{array}$ & Mental & $\begin{array}{l}\text { Faculdade de } \\
\text { Medicina de } \\
\text { Barbacena } \\
\text { (Fame) } \\
\text { [Medicine } \\
\text { School of } \\
\text { Barbacena] }\end{array}$ & $\begin{array}{l}\text { Adult PCC - } \\
\text { Barbacena } \\
\text { (MG) }\end{array}$ & 583 & $\begin{array}{l}\text { Medical } \\
\text { records }\end{array}$ & $\begin{array}{l}56.6 \% \text { were men with average age of } 38.7 \\
3.6 \text { years; } 48.8 \% \text { of them are married or } \\
\text { are in a stable relationship; } 60 \% \text { have low } \\
\text { education level, } 11.9 \% \text { have a job; } 64.7 \% \\
\text { have history of psychiatric treatment; } \\
28.8 \% \text { have psychotic outbreaks. The } \\
\text { family helped in the guiding of patients } \\
\text { to this service. }\end{array}$ \\
\hline 9 & $\begin{array}{l}\text { Santos et al. (2013) } \\
\text { Epidemiological profile } \\
\text { of users of a Psychosocial } \\
\text { Care Center. }\end{array}$ & $\begin{array}{l}\text { Revista de } \\
\text { Enfermagem } \\
\text { UFPE Online } \\
\text { [Journal of } \\
\text { nursing UFPE } \\
\text { Online] }\end{array}$ & $\begin{array}{l}\text { Federal } \\
\text { University of } \\
\text { Alagoas (Ufal) }\end{array}$ & $\begin{array}{l}\text { Adult PCC - } \\
\text { Maceió (AL) }\end{array}$ & 268 & $\begin{array}{l}\text { Medical } \\
\text { records }\end{array}$ & $\begin{array}{l}65.5 \% \text { were women; } 40.6 \% \text { of them aging } \\
40 \text { to } 49 \text { years; and } 33.6 \% \text { did not fin- } \\
\text { ish basic education. The predominant } \\
\text { diagnostics were: schizophrenia ( } 53.9 \% \text { ), } \\
\text { mood disorders ( } 35.7 \%) \text {, and neurotic } \\
\text { disorders ( } 10.4 \%) \text {. The most common } \\
\text { comorbidity was arterial hypertension } \\
(31.3 \%)\end{array}$ \\
\hline 10 & $\begin{array}{l}\text { Araújo et al. (2012) } \\
\text { Clinical and } \\
\text { sociodemographic } \\
\text { profile of adolescents } \\
\text { who remained and not } \\
\text { remained under treatment } \\
\text { in a adPCC of Cuiabá, MT. }\end{array}$ & $\begin{array}{l}\text { Jornal Brasileiro } \\
\text { de Psiquiatria } \\
\text { [Brazilian } \\
\text { Journal of } \\
\text { Psychiatry] }\end{array}$ & $\begin{array}{l}\text { Federal } \\
\text { University of } \\
\text { Mato Grosso } \\
\text { (UFMT) }\end{array}$ & $\begin{array}{l}\text { adPCC } \\
\text { Adolescer - } \\
\text { Cuiabá (MT) }\end{array}$ & 125 & $\begin{array}{l}\text { Medical } \\
\text { records }\end{array}$ & $\begin{array}{l}\text { Single men from } 15 \text { to } 17 \text { years with some } \\
\text { elementary education and no occupa- } \\
\text { tion who made use of psychoactive } \\
\text { substances - and were guided to this } \\
\text { service by social and judicial sectors } \\
\text { - that despite having a problematic } \\
\text { relationship with their families, had } \\
\text { their constant support during treatment. }\end{array}$ \\
\hline II & $\begin{array}{l}\text { Freitas and Souza (2010) } \\
\text { Clinical and } \\
\text { sociodemographic } \\
\text { characterization of users } \\
\text { of a Psychosocial Care } \\
\text { Center }\end{array}$ & $\begin{array}{l}\text { Revista Baiana } \\
\text { de Saúde } \\
\text { Pública [Public } \\
\text { Health Journal } \\
\text { of Bahia] }\end{array}$ & $\begin{array}{l}\text { State University } \\
\text { of Santa Cruz } \\
\text { (Uesc) }\end{array}$ & $\begin{array}{l}\text { Adult PCC - } \\
\text { Ilhéus (BA) }\end{array}$ & 223 & $\begin{array}{l}\text { Medical } \\
\text { records }\end{array}$ & $\begin{array}{l}52 \% \text { were men with average age of } \\
43 \text { years; } 16 \% \text { of them were retired or } \\
\text { received some kind of benefit; only } 2 \% \\
\text { had no religion; } 40.4 \% \text { had an income } \\
\text { from I to } 3 \text { minimum wages. The most } \\
\text { common diagnosis was schizophrenia } \\
\text { ( } 30 \%) ; 45 \% \text { of users were registered in } \\
\text { the non-intensive service; } 70.4 \% \text { used } \\
\text { anticonvulsants and antiepileptics. }\end{array}$ \\
\hline
\end{tabular}




\begin{tabular}{|c|c|c|c|c|c|c|c|}
\hline & Article & Journal & $\begin{array}{l}\text { Institutional } \\
\text { affiliation of the } \\
\text { authors }\end{array}$ & Local of study & $\begin{array}{l}\text { Size of the } \\
\text { sample }\end{array}$ & $\begin{array}{l}\text { Empirical } \\
\text { material }\end{array}$ & Synthesis of the users' profile \\
\hline 12 & $\begin{array}{l}\text { Hoffmann, Santos and } \\
\text { Mota (2008) } \\
\text { Characterization of } \\
\text { users and of the services } \\
\text { provided Children and } \\
\text { Adolescents Psychosocial } \\
\text { Care Centers }\end{array}$ & $\begin{array}{l}\text { Cadernos de } \\
\text { Saúde Pública } \\
\text { [Notes on Public } \\
\text { Health] }\end{array}$ & $\begin{array}{l}\text { Ministry } \\
\text { of Health } \\
\text { and Federal } \\
\text { University of } \\
\text { Bahia (Ufba) }\end{array}$ & $\begin{array}{l}\text { caPCC - } \\
\text { Contagem, } \\
\text { Uberlândia } \\
\text { and Uberaba } \\
\text { (MG); Cuiabá } \\
\text { (MT); Cambé } \\
\text { and Londrina } \\
\text { (PR); Sorocaba } \\
\text { (SP) }\end{array}$ & 1,456 & $\begin{array}{l}\text { Data bank } \\
\text { from the } \\
\text { Outpatient } \\
\text { Information } \\
\text { System }\end{array}$ & $\begin{array}{l}62.8 \% \text { were men with average age of } 11.1 \\
\text { years; } 78 \% \text { of them were diagnosed for } \\
\text { three groups from ICDIO, } 44.5 \% \text { for the } \\
\text { group of behavioral and emotional dis- } \\
\text { orders, } 19.8 \% \text { for neurotic disorders, and } \\
14.2 \% \text { for disorders of psychological trait. }\end{array}$ \\
\hline 13 & $\begin{array}{l}\text { Pelisoli and Moreira } \\
\text { (2007) } \\
\text { Assessment of a } \\
\text { Psychosocial Care Center } \\
\text { from the profile of its } \\
\text { users }\end{array}$ & Mental & $\begin{array}{l}\text { Federal } \\
\text { University of } \\
\text { Rio Grande do } \\
\text { Sul (UFRGS) and } \\
\text { CNEC Faculty of } \\
\text { Osório (Facos) }\end{array}$ & $\begin{array}{l}\text { Adult PCC - } \\
\text { Osório (RS) }\end{array}$ & 65 & $\begin{array}{l}\text { Medical } \\
\text { records }\end{array}$ & $\begin{array}{l}\text { Women; average age of } 28.8 \text { years; } 27 \% \\
\text { of them were students; with a prevalence } \\
\text { of } 33.8 \% \text { of mood disorders. Represented } \\
72 \% \text { of interdisciplinary care. }\end{array}$ \\
\hline 14 & $\begin{array}{l}\text { Balarin, Miranda and } \\
\text { Carvalho (20II) } \\
\text { Psychosocial Care Center } \\
\text { of the city of Campinas: } \\
\text { study on the clinical and } \\
\text { sociodemographic profile } \\
\text { of users }\end{array}$ & $\begin{array}{l}\text { Journal of } \\
\text { Medical } \\
\text { Sciences }\end{array}$ & PUC-Campinas & $\begin{array}{l}\text { Adult* PCC - } \\
\text { Campinas (SP) }\end{array}$ & 85 & $\begin{array}{l}\text { Medical } \\
\text { records }\end{array}$ & $\begin{array}{l}53.7 \% \text { were men who had average age of } \\
41.2 \text { years; } 54.1 \% \text { of them were single; } 32.9 \% \\
\text { had some elementary school; } 76.4 \% \text { had no } \\
\text { job; } 67 \% \text { were diagnosed with schizophre- } \\
\text { nia, schizotypal or delusional disorders; } \\
\text { and } 91.4 \% \text { of them used antipsychotics. } \\
\text { A percentage of } 43.4 \% \text { of these men were } \\
\text { guided by a Health Center, and } 67 \% \text { of them } \\
\text { underwent psychiatric hospitalization. }\end{array}$ \\
\hline 15 & $\begin{array}{l}\text { Pereira et al. (2012) } \\
\text { Profile of the users of } \\
\text { Mental Health Services of } \\
\text { the city of Lorena - São } \\
\text { Paulo }\end{array}$ & $\begin{array}{l}\text { Acta Paulista } \\
\text { de Enfermagem } \\
\text { [Nursing } \\
\text { Register of the } \\
\text { state of São } \\
\text { Paulo) }\end{array}$ & $\begin{array}{l}\text { Teresa D'Ávila } \\
\text { Integrated } \\
\text { Schools (Fatea) } \\
\text { and University } \\
\text { of São Paulo } \\
\text { (USP) }\end{array}$ & $\begin{array}{l}\text { Adult PCC- } \\
\text { Lorena (SP) }\end{array}$ & 340 & $\begin{array}{l}\text { Medical } \\
\text { records }\end{array}$ & $\begin{array}{l}61 \% \text { were men; } 73 \% \text { of them were white; } \\
\text { aged } 47.9 \text { years in average; } 50 \% \text { had } \\
\text { some elementary school; } 20.5 \% \text { had no } \\
\text { jobs and stayed at home. The most com- } \\
\text { mon diagnosis ( } 25.8 \% \text { ) was of mental } \\
\text { and behavioral disorders due to the use } \\
\text { of psychoactive substances, and the } \\
\text { most commonly prescribed medications } \\
(44.7 \% \text { ) were antipsychotics. }\end{array}$ \\
\hline 16 & $\begin{array}{l}\text { Nascimento et al. (2014) } \\
\text { Profile of children treated } \\
\text { by Psychosocial Care } \\
\text { Centre for Children and } \\
\text { Adolescents }\end{array}$ & $\begin{array}{l}\text { Revista de } \\
\text { Enfermagem } \\
\text { da UFPE Online } \\
\text { [UFPE Nursing } \\
\text { Journal Online] }\end{array}$ & $\begin{array}{l}\text { Federal } \\
\text { University of } \\
\text { Alagoas (Ufal) }\end{array}$ & $\begin{array}{l}\text { caPCC - } \\
\text { Maceió (AL) }\end{array}$ & 132 & $\begin{array}{l}\text { Medical } \\
\text { records }\end{array}$ & $\begin{array}{l}\text { About } 74.2 \% \text { were men; } 36.4 \% \text { of them were } \\
\text { between } 9 \text { and II years; } 34.1 \% \text { between } 15 \text { and } \\
18 \text { years; } 36.4 \% \text { lived with their parents. The } \\
\text { most frequent diagnosis }(61.3 \% \text { ) was mental } \\
\text { retardation; } 96.2 \% \text { of patients consumed } \\
\text { psychoactive drugs; } 56.1 \% \text { of them used to } \\
\text { go to PCCs three times a week; and } 2.4 \% \text { had } \\
\text { a history of psychiatric hospitalization. }\end{array}$ \\
\hline 17 & $\begin{array}{l}\text { Rodrigues et al. (2012) } \\
\text { Demographic profile, } \\
\text { diagnosis and psychiatric } \\
\text { hospitalization of users } \\
\text { of the Psychosocial Care } \\
\text { Network of Rio Grande } \\
\text { do Sul }\end{array}$ & $\begin{array}{l}\text { Journal Nursing } \\
\text { Health }\end{array}$ & $\begin{array}{l}\text { Federal } \\
\text { University of } \\
\text { Pelotas (Ufpel) }\end{array}$ & $\begin{array}{l}\text { Adult PCC } \\
* * \text { - Alegrete, } \\
\text { Bagé, Caxias } \\
\text { do Sul, Porto } \\
\text { Alegre, } \\
\text { Viamão (RS) }\end{array}$ & 249 & $\begin{array}{l}\text { Interview } \\
\text { with Adult } \\
\text { PCC users }\end{array}$ & $\begin{array}{l}51.41 \% \text { were men, } 68.62 \% \text { with age between } \\
35 \text { and } 59 \text { years; } 21.8 \% \text { of them were retired; } \\
61.30 \% \text { reported consider themselves as } \\
\text { white; } 61 \% \text { were single; and } 41.16 \% \text { attended } \\
\text { elementary school for a while. The most } \\
\text { frequent diagnosis was depressive disorder } \\
\text { (35\%), followed by schizophrenia (30.70\%). } \\
62.2 \% \text { have already undergone psychiatric } \\
\text { hospitalization. }\end{array}$ \\
\hline
\end{tabular}

* Also analyzed medical records of Outpatient Care on Mental Health

** Also interviewed users of therapeutic residence services. 


\section{Chart 2 - Race/color characterization of users of PCCs according to articles analyzed and the black population of their respective states, São Paulo, 2015}

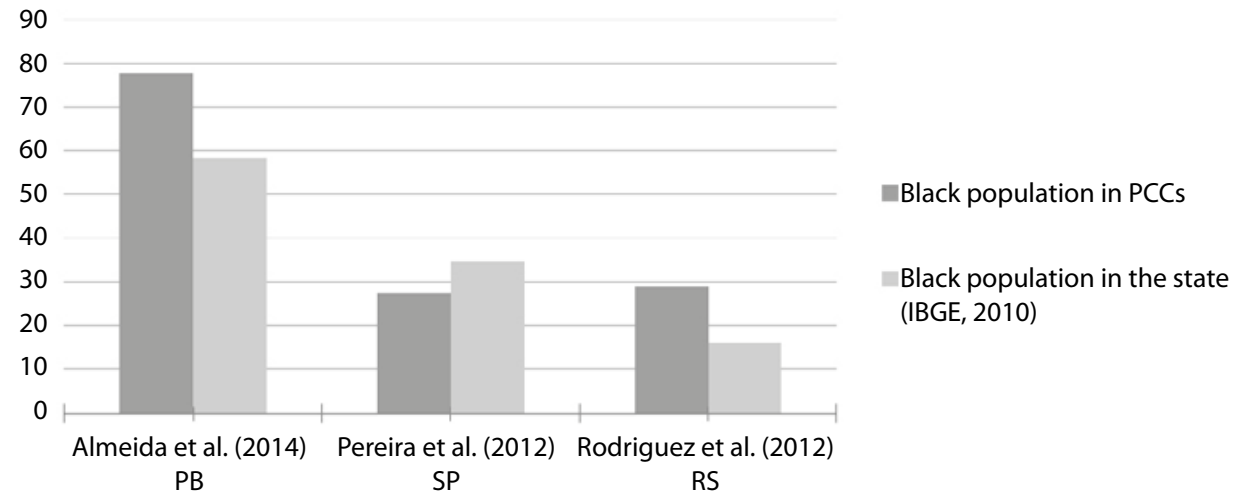

\section{Discussion}

According to scientific literature, male predominance among PCCs patients can be due to stereotypes imposed by society. These stereotypes determine the expected behaviors and boundaries from the sexes, allowing for men and women to have different experiences, (Almeida et al., 2014) which favors men affected by mental and behavioral disorders from the use of alcohol and drugs and schizophrenia (Miranda; Tarasconi; Scortegagna, 2008). In addition, the low prevalence of female population (especially in adPCCs) can be explained by the discrimination that women addicted to alcohol and/or drugs face besides having to deal with feelings of guilt, shame, fear, and dependence (Araújo et al., 2012).

Contrary to these data, we found out that women and mood disorders are in higher number in 6 of 17 articles (over 30\%). According to the analyzed articles, the reason why such peculiarities on sexes and diagnoses are prevalent in PCCs is that some institutions configured as PCCs only address cases of common mental disorders from the general population, which should be responsibility of a Basic Health Unit (BHU). As seen in one of the studied articles, the treatment of a wider public is justified by the history of PCCs, since before the psychiatric reform this institution was an outpatient service responsible for less severe patients, while more severe cases were guided to hospitalization in psychiatric hospitals (Pelisoli; Moreira, 2007).
We highlight that, as reported by the Brazilian Ministry of Health, PCCs must help individuals in intense psychic suffering, i.e., people with severe and persistent mental disorders caused by the use of psychoactive substances who are not able to follow their life projects, which hinders their possibilities of living life at its fullest (Brasil, 2004).

According to the analyzed articles, users of PCCs present low education level and a high unemployment rate, which shows the vulnerability of this population and the little investment of these services towards work as a rehabilitating tool. Education is an important qualifier for professional occupations and consequently determines the income of these individuals; hence, the low education level reflects on social and material matters, providing different life conditions to people (Ludermir; Melo Filho, 2002). The lack of qualifications of PCCs users leads them to easily replaced jobs, which explains a high unemployment rate in a very competitive job market.

Education, work and housing are the center of psychosocial rehabilitation (Saraceno, 2012), becoming a factor of inclusion or exclusion of individuals in society; this way, considering that PCCs users are in disadvantage regarding these three questions, it is up to this service promote ways of helping the patients improvements within their possibilities, thus increasing their social participation and trustability towards society. When assessing the users of PCCs among the black population, we infer that being black is a characteristic that is considered a 
disadvantage; as reported in the introduction of this article, black people in Brazil have lower access to higher education institutions and have a higher unemployment rate when compared with white people.

This review of the literature shows that Brazilian studies on mental health, the use of the race/color variable to characterize users of health services is still reduced - which is confirmed by Araújo et al. (2009) -, despite being an important social marker.

"Brazil has prejudice of having prejudice", said Florestan Fernandes, and this prejudice is the center of a very commonly used argument:

the wrong assumption that the inclusion of race/ color variable could be interpreted as a discriminatory and/or racist action. This statement was used by Brazilian health authorities to not include this data in services of the Brazilian Public Health System (SUS) and in statistics produced by it (Giovanetti et al., 2007).

On the other hand, every day we experience cases of racism. For example: when a professional feels uncomfortable to ask the race/color of a person; when in a group of friends only the black person is approached by the police; when a black person walks into a restaurant or a luxury hotel and other people stare at them; in the lack of participation of black models in advertisings of a predominantly black country.

The existence of racial inequalities is also denied by part of our society when equality promotion actions are suggested. It is possible to see in social networks, and even in scientific literature, that equality promotion actions for this population to have health services and education are sometimes negatively seen for treating the black population "differently" compared with the other ones - this is the moment when some people use the argument that we are all "biologically" the same as members of the "human race". By not recognizing racial inequalities influence in people's access to rights and not understanding and supporting equality promotion actions, our society ends up increasing inequities.

Another aspect that can be associated with the limited use of the race/color variable in scientific productions on health is how terms such as ethnicity, race, and color are defined (Languardia, 2004). There are conflicting points of view on the meaning and usage of the term "race", since it does not have scientific rigor in its definition. Sometimes, variables "ethnicity" and "race" are used as risk factors in epidemiological research; in social research, these variables are part of the process of social determination of a certain disease. The different definitions of race available in the literature limit the use of the race/color variable and are due to the sociopolitical positions, concepts, methods of analysis and instruments used by the authors in their studies (Laguardia, 2004). In Brazilian scientific literature, it is not usual to use the term "ethnicity" to refer to social groups, as it occurs in other countries. In Brazil, the term "race" is most commonly used.

Researchers of the health field that ignore the knowledge produced by social research show difficulty in using the race/color variable. Our hypothesis is that health researchers lack information on the importance of the race/color variable to understand how social matters are determining factors in the development of mental disorders and also do not recognize the centrality of racial-ethnic dimension in the configuration and reproduction of social inequalities.

Pereira et al. (2012) and Rodrigues et al. (2012) showed most users of PCCs are white. When comparing the data presented with the proportion of black people by state, the portion of black patients of PCCs studied by Almeida et al. (2014) and Rodrigues et al. (2012) is higher than the black population in their respective states; in Pereira et al. (2012), this proportion is lower than the general black population, which allows us to reflect on the inclusion of black population in health services as PCCs (IBGE, 2014).

The study conducted by the Batista, Escuder and Pereira (2004) found that, proportionally, in the State of São Paulo, black and brown people die more than white people for mental disorders. Barros et al. (2014) identified a higher proportion of black population (black and brown people) hospitalized in psychiatric hospitals of the state of São Paulo. This context raises some questions: what services they attended before being hospitalized or passed away? 
Does black population get sick and die without having access to PCCs or Basic Health Units?

According to Lopes (2004), black and white people have the same diseases, but the intensity in which it occurs and how it is taken care of is different - black population is born, lives, gets sick and dies differently when compared with the white one. Despite not living with the pain of slavery anymore, black population still suffers with the stigma of social exclusion and segregation, remaining the poorest ones as they receive lower incomes and having restricted and precarious access to infrastructure services and good quality health care when compared with the white population (Araújo et al., 2009). This situation in health services and the precariousness of care regarding black people shows that the racial prejudice influences the relationship between health professionals and patients (Domingues et al., 2013).

This unequal treatment is justified by the idea that black people are inferior to white people due to the social meaning attributed to some phenotypic and genetic characteristics seen as negative by the ones who are different - a characteristic of racism that is consciously or unconsciously played by people over time, even with the evolution of societies, historical conjunctures and group interests, this way creating and multiplying the vulnerabilities of this population (Lopes, 2004). Considering what was said previously, it is obvious that the nonreproduction of racial prejudice is highly unlikely and uncertain, as it is intrinsic to society. However, racial equality promotion actions provided by the Law No.12,288 of July 2oth of 2010 and imposed by the Statute of Racial Equality ensure universal and equal access to any kind of health service for the black population (Brazil, 2010), aiming to reduce the inequalities observed throughout history.

Faro and Pereira (2011) reviewed literature on the relation of racism with the stress and they have not found Brazilian texts on the subject; considering international texts, the authors concluded that racial minorities tend to be more exposed to specific stressing situations, such as the ones regarding discrimination, prejudice and social segregation, reinforcing inequality in social distribution stress. Kwate and Goodman (2015) call the attention to the emotional pain that people exposed to racism feel and consequently to the damages to mental health it can also bring. Williams and Williams-Morris (2000) suggest that racism can negatively affect people's mental health status in at least three ways: (1) racism in the social institutions can lead to the lack of socioeconomic mobility, in addition to the differences regarding the access to services and poor living conditions, which can negatively affect mental health; (2) experiences of discrimination can induce physiological and psychological reactions that can affect people's mental health status; and (3), in raeconscious societies, accepting negative stereotypes can lead to unfavorable self-assessments, which have damaging effects on psychological well-being.

\section{Final remarks}

Recently, the interest in the psychosocial effects of racism has become a way of interpreting mental health care in Brazil, but still there is not an enough amount of Brazilian scientific publications on this subject.

The literature review of studies concerning mental health research in Brazil allowed us to note that the use of the race/color variable to characterize PCCs patients is still reduced, despite being an important social marker. This meets the way how Brazilian society deals with racial inequalities: as they were not real, which ends up reinforcing them. Since these inequalities have shown to be persistent, they require actions and public policies be taken, changing the situation lived by the black population.

To include information on race/color in health services is important to monitor and evaluate the actions for the promotion of racial equality defended by the Statute of Racial Equality, which guarantees universal and equal access to any type of health service for the black population.

Taking this item into account in studies and health services is an important indicator considering both social movements and research on this matter can help in the elaboration and promotion of public policies that are aimed at reducing social inequalities when it comes to health. Thus, we recommend the inclusion of the race/color variable 
in research on the mental health field; as for data analysis, we recommend to use it as an analysis category.

The use of the race/color variable in research or its use as an analysis category can generate scientific evidence on racism as a producer of distress and contribute to the performance of services, management and civil society/social control. There is need for mental health policies start discussing strategies that go beyond conferences recommendations to face this situation; so that researchers would be able to create and then share knowledge on such issue in a more detailed way, contributing to the elaboration and implementation of these strategies.

\section{References}

ALMEIDA, R. A. et al. Perfil dos usuários de substâncias psicoativas de João Pessoa. Saúde em Debate, Rio de Janeiro, v. 38, n. 102, p. 526-538, 2014 .

ARAÚJO, E. M. et al. A utilização da variável raça/ cor em Saúde Pública: possibilidades e limites. Interface - Comunicação, Saúde, Educação, Botucatu, v. 13, n. 31, p. 383-394, 2009.

ARAÚJO, N. B. et al. Perfil clínico e sociodemográfico de adolescentes que permaneceram e não permaneceram no tratamento em um CAPSad de Cuiabá/MT. Jornal Brasileiro de Psiquiatria, Rio de Janeiro, v. 61, n. 4, p. 227-234, 2012.

BALARIN, M. L. G. S.; MIRANDA, I. M. S.; CARVALHO, C. M. Centro de Atenção Psicossocial do município de Campinas: estudo sobre o perfil sociodemográfico e clínico de seus usuários. Revista de Ciências Médicas, Campinas, v. 20, n. 3-4, p. 59-67, 2011.

BARBOSA, M. I. S. Racismo e saúde. 1988. Tese (Doutorado em Saúde Materno-Infantil) Faculdade de Saúde Pública da Universidade de São Paulo, São Paulo, 1998.

BARROS, S.; BICHAFF, R. (Org.). Desafios para a desinstitucionalização: censo psicossocial dos moradores em hospitais psiquiátricos do Estado de São Paulo. São Paulo: Fundap, 2008.
BARROS, S.; CAMPOS, P. F. de S.; FERNANDES, J. J. (Org.). Atenção à saúde de populações vulneráveis. São Paulo: Manole, 2014.

BARROS, S. et al. Censo psicossocial dos moradores em hospitais psiquiátricos do estado de São Paulo: um olhar sob a perspectiva racial. Saúde e Sociedade, São Paulo, v. 23, n. 4, p. 12351247, 2014.

BATISTA, L. E.; ESCUDER, M. M. L.; PEREIRA, J. C. R.. A cor da morte : causas de óbito segundo características de raça no Estado de São Paulo, 1999 a 2001. Revista de Saúde Pública, São Paulo, v. 38, n. 5, p. 63o-636, 2004.

BELLETTINI, F. E.; GOMES, K. M. Perfil dos usuários do Centro de Atenção Psicossocial e do Programa de Saúde Mental no município de Orleans - SC. Cadernos Brasileiros de Saúde Mental, Florianópolis, v. 5, n. 12, p. 161-175, 2013.

BRASIL. Ministério da Saúde. Departamento de Ações Programáticas Estratégicas. Saúde mental no SUS: os centros de atenção psicossocial. Brasília: Ministério da Saúde, 2004.

BRASIL. Presidência da República. Lei $n^{0}$ 12.288, de 20 de julho de 2010. Institui o Estatuto da Igualdade Racial; altera as Leis $\mathrm{n}^{\text {os }} 7 \cdot 716$, de 5 de janeiro de 1989, 9.029, de 13 de abril de 1995, 7.347, de 24 de julho de 1985 , e 10.778 , de 24 de novembro de 2003 . Diário Oficial [da] República Federativa do Brasil, Brasília, DF, 21 set. 2010.

CARVALHO, M. D. A.; SILVA, H. O.; RODRIGUES, L. V. Perfil epidemiológico dos usuários da rede de saúde mental do município de Iguatu, CE. SMAD - Revista Eletrônica Saúde Mental Álcool e Drogas, Ribeirão Preto, v. 6, n. 2, p. 337-349, 2010.

COSTA, R. C. et al. Perfil epidemiológico de usuários intensivos de um Centro de Atenção Psicossocial. Revista de Enfermagem UFPE Online, Recife, v. 9, n. 2, edição suplementar, p. 820-829, 2015.

DOMINGUES, P. M. L. et al. Discriminação racial no cuidado em saúde reprodutiva na percepção de mulheres. Texto \& Contexto Enfermagem, Florianópolis, v. 22, n. 2, p. 285-292, 2013. 
FARO, A.; PEREIRA, M. E. Raça, racismo e saúde: a desigualdade social da distribuição do estresse. Estudos de Psicologia (Natal), Natal, v. 16, n. 3, p. 271-278, 2011.

FREITAS, A. A. E.; SOUZA, R. C. Caracterização clínica e sociodemográfica dos usuários de um Centro de Atenção Psicossocial (CAPS). Revista Baiana de Saúde Pública, Salvador, v. 34, n. 3 , p. 530-543, 2010.

GIOVANETTI, M. R. et al. A implantação do quesito cor/raça nos serviços de DST/Aids no Estado de São Paulo. Saúde e Sociedade, São Paulo, v.16, n. 2, p. 163-170, 2007.

HOFFMANN, M. C. C. L.; SANTOS, D. N.; MOTA, E. L. A. Caracterização dos usuários e dos serviços prestados por Centro de Atenção Psicossocial Infanto-Juvenil. Cadernos de Saúde Pública, Rio de Janeiro, v. 24, n. 3, p. 633-642, 2008.

IBGE - INSTITUTO BRASILEIRO DE GEOGRAFIA E ESTATÍSTICA. Indicadores de cor ou raça, segundo a Pesquisa Mensal de Emprego março de 20o9. Brasília, DF, 2009. Disponível em: <http:// bit.ly/2jbSXpB>. Acesso em: 28 jun. 2015.

IBGE - INSTITUTO BRASILEIRO DE GEOGRAFIA E ESTATÍSTICA. Censo demográfico 2010: características gerais da população, religião e pessoas com deficiência. Rio de Janeiro, 2012. Disponível em: <http://bit.ly/1RCBs7H>. Acesso em: 28 jun. 2015 .

IBGE - INSTITUTO BRASILEIRO DE GEOGRAFIA E ESTATÍSTICA. Pesquisa nacional por amostra de domicílios: Tabela 262, população residente, por cor ou raça, situação e sexo. 2014. Disponível em: <http://bit.ly/2niajUK>. Acesso em: 13 dez. 2015 .

KWATE, N. O.; GOODMAN, M. S. Cross-sectional and longitudinal effects of racism on mental health among residents of black neighborhoods in New York City. American Journal of Public Health, Newark, v. 105, n. 4, p. 711-718, 2015.

LAGUARDIA, J. O uso da variável "raça" na pesquisa em saúde. Physis - Revista de Saúde Coletiva, Rio de Janeiro, v. 14, n. 2, p. 197-234, 2004 .
LOPES, F. Experiências desiguais ao nascer, viver, adoecer e morrer: tópicos em saúde da população negra no Brasil. In: SEMINÁRIO SAÚDE DA POPULAÇÃO NEGRA, 1., 2004, Brasília, DF. Anais... Disponível em: <http://bit.ly/1zS4biy>. Acesso em: 26 jun. 2015.

LOPES, F. Para além da barreira dos números: desigualdades raciais e saúde. Cadernos de Saúde Pública, Rio de Janeiro, v. 21, n. 5, p. 1595-16o1, 2005 .

LUDERMIR, A. B.; MELO FILHO, D. A. M. Condições de vida e estrutura ocupacional associadas a transtornos mentais comuns. Revista Saúde Pública, São Paulo, v. 36, n. 2, p. 213-221, 2002.

MACDONALD, D.; POPE, R.; ORR, R. M.

Differences in physical characteristics and performance measures of part-time and fulltime tactical personnel: a critical narrative review. Journal of Military and Veterans' Health, Hobart, v. 24, n. 1, p. 45-55, 2016.

MANGUALDE, A. A. S. et al. Perfil epidemiológico dos pacientes atendidos em um Centro de Atenção Psicossocial. Mental, Barbacena, v. 10, n. 19, p. 235-248, 2013 .

MELO, M. F. S.; SILVANY NETO, A. M. Perfil de morbidade, aspectos ergonômicos e psicossociais, fadiga e perturbação do ciclo circadiano de pilotos de aviação comercial: uma revisão narrativa.

Revista Baiana de Saúde Pública, Salvador, v. 36, n. 3, p. 683-698, 2012.

MIRANDA, C. A.; TARASCONI, C. V.; SCORTEGAGNA, S. A. Estudo epidêmico dos transtornos mentais. Avaliação Psicológica, Itatiba, v. 7, n. 2, p. 249-257, 2008.

NASCIMENTO, Y. C. M. L. et al. Perfil de crianças e adolescentes acompanhados por um centro de atenção psicossocial infanto-juvenil. Revista de Enfermagem UFPE Online, Recife, v. 8, n. 5, p. 12611272, 2014.

NORONHA, D. P.; FERREIRA, S. M. S. P. Revisões de literatura. In: CAMPELLO, B. S. V. C.; CENDÓN, B. V.; KREMER, J. M. (Org.). Fontes de informação 
para pesquisadores e profissionais. Belo Horizonte: UFMG, 2000.

OLIVEIRA, E. N. et al. Caracterização da clientela atendida em Centro de Atenção Psicossocial álcool e drogas. Revista Rene, Fortaleza, v. 14, n. 4, p. 748-756, 2013.

PELISOLI, C. L.; MOREIRA, A. K. Caracterização epidemiológica dos usuários do Centro de Atenção Psicossocial Casa Aberta. Revista Psiquiátrica do Rio Grande do Sul, Porto Alegre, v. 27, n. 3, p. 270277, 2005 .

PELISOLI, C. L.; MOREIRA, A. K. Avaliação de um centro de atenção psicossocial por meio do perfil de seus usuários. Mental, Barbacena, v. 5, n. 8, p. $61-75,2007$.

PEREIRA, M. O. et al. Perfil dos usuários de Serviços de Saúde Mental do município de Lorena - São Paulo. Acta Paulista de Enfermagem, São Paulo, v. 25, n. 1, p. 48-54, 2012.

PIETERSE, A. L. et al. Perceived racism and mental health among black american adults: a meta-analytic review. Journal of Counseling Psychology, Columbus, v. 59, n. 1, p. 1-9, 2012.

PRIEST, N. et al. Experiences of racism, racial/ ethnic attitudes, motivated fairness and mental health outcomes among primary and secondary school students. Journal of youth and adolescence, New York, v. 43, n. 10, p. 1672-1687, 2014.

RODRIGUES, C. G. S. S. et al. Perfil sociodemográfico, diagnóstico e internação psiquiátrica de usuários da Rede de Atenção Psicossocial do Rio Grande do Sul. Journal
Nursing Health, Pelotas, v. 2, suplemento de saúde mental, p. 141-150, 2012.

RODRIGUES, L. S. A. et al. Perfil dos usuários atendidos em um Centro de Atenção Psicossocial: Álcool e drogas. Revista de Enfermagem UFPE Online, Recife, v. 7, n. 8, p. 5191-5197, 2013.

ROSA, C. M.; VILHENA, J. Do manicômio ao CAPS da contenção (im)piedosa à responsabilidade. Barbarói, Santa Cruz do Sul, n. 37, p. 154-176, 2012.

SANTOS, G. F. et al. O perfil epidemiológico dos usuários de um Centro de Atenção Psicossocial. Revista de Enfermagem UFPE Online, Recife, v. 7, n. 3, p. 679-687, 2013.

SARACENO, B. Reabilitação psicossocial: uma estratégia para a passagem do milênio. In: PITTA, A. (Org.). Reabilitação Psicossocial no Brasil. São Paulo: Hucitec, 2012. p. 13-18.

TRAPÉ, T. L.; CAMPOS, R. O.; GAMA, C. A. P. Mental health network: a narrative review study of the integration assistance mechanisms at the Brazilian National Health System. International Journal of Health Sciences, New Delhi, v. 3, n. 3, p. 45-53, 2015.

WILLIAMS, D. R.; WILLIAMS-MORRIS, R. Racism and mental health: the African American experience. Ethnicity and Health, Abingdon, v. 5, n. 3-4, p. 243-268, 2000.

\section{Authors' contribution}

Barros and Silva contributed to the development of the idea, to the writing and critical analysis of this article. Azevedo, Policarpo and Silva participated in the process of data collection, organization and analysis. Batista helped with the writing and critical analysis of the article.

Received: 06/07/2016

Accepted: $11 / 17 / 2016$ 